\title{
Gastrointestinal protozoa in dairy calves: identification of risk factors for infection
}

\section{Protozoos gastrointestinales en terneros lecheros: identificación de factores de riesgo para la infección}

\author{
Andreia Volpato 1 M.Sc, Alexandre Alberto Tonin² Ph.D, Gustavo Machado 3 Ph.D, \\ Lenita Moura Stefani ${ }^{1}$ Ph.D, Gabriela Campigotto ${ }^{1}$ M.Sc, Patricia Glombowsky ${ }^{1}$ M.Sc, \\ Gabriela Miotto Galli ${ }^{1}$ M.Sc, Juscivete Fatima Favero ${ }^{1}$ M.Sc, Aleksandro Schafer da Silva ${ }^{1 *}$ Ph.D.
}

\begin{abstract}
${ }^{1}$ Universidade do Estado de Santa Catarina (UDESC), Department of Animal Science, Chapecó, SC, Brazil. 'Universidade do Oeste de Santa Catarina (UNOESC), Department of Veterinary Medicine, Xanxerê, SC, Brazil. 3Universidade Federal do Rio Grande do Sul, Department of Veterinary Medicine, Porto Alegre, RS, Brazil. Correspondence: aleksandro ss@yahoo.com.br
\end{abstract}

Received: June 2016; Accepted: January 2017.

\begin{abstract}
Objective. This study aimed to evaluate the occurrence of gastrointestinal protozoa in dairy calves and to identify potential risk factors for this type of infection. Materials and methods. For this purpose, 243 fecal samples were collected from calves up to 60 days of age in 43 dairy farms located in the West region of Santa Catarina state, Brazil. Samples were examined by centrifugal-flotation technique. Results. As a result, Giardia was present in $26.75 \%(65 / 243)$ of all samples, Eimeria in $21.81 \%$ (53/243), and Cryptosporidium in 20.99\% (51/243). Additionally, $46.50 \%(113 / 243)$ of the samples were negative for any protozoa, while 39.10\% (95/243) and $14.40 \%$ (35/208) showed single and mixed infections, respectively. There was a higher association between Cryptosporidium and Giardia (6.99\%) in cases of mixed infections. However, the triple protozoa association had the lowest prevalence in mixed infections (2.06\%). Epidemiologically, a questionnaire was applied to determine risk factors for these parasitic infections. Based on the statistical model applied, some risk factors for Cryptosporidium infections were identified, highlighting feeding management, period of time that calves stayed with their mothers (cows), and contact with dogs; the risk of contracting Giardia increased according to the milk source, while the floor type bedding, and age were appointed as risks factors for Eimeria. Conclusions. Therefore, it is possible to confirm that Giardia, Cryptosporidium and Eimeria may infect dairy calves, and the knowledge of some risk factors associated to their infection in calves.
\end{abstract}

Keywords: Cryptosporidium spp., dairy cattle, Eimeria spp, Giardia spp., parasitic diseases (Source: $C A B, M e S H)$.

\section{RESUMEN}

Objetivo. El objetivo evaluar la ocurrencia de protozoos gastrointestinales en terneros lecheros y de identificar posibles factores de riesgo para infección. Materiales y métodos. Se recogieron 243 muestras de heces de terneros de hasta 60 días de edad en 43 granjas lecheras ubicadas en la región del oeste del estado de Santa Catarina, Brasil. Las muestras fueron examinadas por la técnica de centrifugación-flotación. Resultados. Como resultado, Giardia estaba presente en $26.75 \%$ (65/243) de todas las muestras, Eimeria en $21.81 \%$ (53/243), y Cryptosporidium en $20.99 \%$ (51/243). 
Además, $46.50 \%(113 / 243)$ de las muestras fueron negativas para cualquier protozoos, mientras que $39.10 \%(95 / 243)$ y $14.40 \%(35 / 208)$ mostraron infecciones simples y mixtas, respectivamente. Hubo una mayor asociación entre Cryptosporidium y Giardia (6.99\%) en los casos de infecciones mixtas. Sin embargo, la asociación de triple protozoos tenía la menor prevalencia de infecciones mixtas $(2.06 \%)$. Epidemiológicamente, se aplicó un cuestionario para determinar los factores de riesgo para estas infecciones parasitarias. Se han identificado algunos factores de riesgo de infecciones por Cryptosporidium, destacando manejo de la alimentación, periodo de tiempo que los terneros permanecieron con sus madres (vacas), y el contacto con los perros; el riesgo de contraer Giardia incrementado en función de la fuente de la leche, mientras que el tipo de suelo de las camas, y la edad fueron nombrados como los riesgos de factores de Eimeria. Conclusiones. Es posible confirmar que Giardia, Cryptosporidium y Eimeria pueden infectar a terneros lecheros, y el conocimiento de algunos factores de riesgo asociados a la infección en terneros.

Palabras clave: Cryptosporidium spp, Eimeria spp, enfermedades parasitarias, ganado lechero, Giardia spp (Fuente: $\mathrm{CAB}, \mathrm{MeSH}$ ).

\section{INTRODUCTION}

Dairy cattle production is an important livestock activity, especially because milk has high nutritional value and it is consumed by most of the world's population. This activity generates income and has social impact for many segments of the production chain, such as producers, processors, equipment suppliers, traders, among others. In Brazil, dairy cattle production has a variety of profiles, that goes from properties with low technological level to those with high standards of production throughout this continental country. According to FAO (1), The United States of America is the largest milk producer $(87,461,300$ tons per year), and Brazil is the fifth largest with an annual production of $31,667,600$ tons per year, corresponding to $5.3 \%$ of the world production.

Dairy cattle business is growing in Brazil and milk production increased 350\% between 1974 and 2011 (2). This growth lead to a solid system for raising heifers, aiming herd replacement; however, producers are still facing some challenges, such as high neonatal mortality. The main cause of early death of calves is diarrhea, mainly caused by infective agents (3-5). Some authors have described diarrhea as the leading cause of death in calves due to dehydration $(3,5)$ during the first two weeks of life up to 3-4 months of age (5). Environmental factors, nutritional issues and infectious agents are usually involved in cases of diarrhea as the protozoa Cryptosporidium spp., Giardia spp. and Eimeria spp. (3-5).

Protozoa of the genus Eimeria Schneider, 1875, may cause coccidiosis in cattle, more often in young animals, and this disease is characterized by diarrhea or dysentery, related to significant economic losses due to the occurrence of high morbidity and mortality, as well as increased costs for prevention and treatment (6). Eimeria is

\section{INTRODUCCIÓN}

La producción de ganado lechero es una actividad ganadera importante, en particular porque la leche tiene un alto valor nutricional y es consumida por la mayor parte de la población mundial. Esta actividad genera ingresos y tiene un impacto social sobre muchos de los segmentos de la cadena de producción, tales como productores, procesadores, proveedores de equipos, comerciantes, entre otros. En Brasil, la producción de ganado lechero tiene diversos perfiles, que van desde propiedades con bajos niveles tecnológicos hasta instalaciones con altos estándares de producción distribuídas a lo largo de este país continental. Según la FAO (1), Estados Unidos es el mayor productor de leche (87.461.300 toneladas al año) y Brasil el quinto con una producción anual de 31.667 .600 toneladas, correspondiente al $5.3 \%$ de la producción mundial.

El negocio del ganado lechero está creciendo en Brasil y su producción lechera aumentó en un $350 \%$ entre 1974 y 2011 (2). Este crecimiento condujo a un sistema sólido de cría de novillas que busca reponer a las manadas. Sin embargo, los productores todavía enfrentan retos tales como la alta mortalidad neonatal. La principal causa de muerte temprana en terneros es la diarrea, causada principalmente por agentes infecciosos (3-5). Algunos autores han descrito que la deshidratación por diarrea es la principal causa de muerte en terneros $(3,5)$ durante las primeras dos semanas de vida hasta los 3-4 meses de edad (5). Los factores ambientales, los problemas nutricionales y los agentes infecciosos tales como los protozoarios Cryptosporidium spp., Giardia spp. y Eimeria spp. (3-5) suelen estar involucrados en casos de diarrea.

Los protozoos del género Eimeria Schneider, 1875 , pueden causar coccidiosis en el ganado, con mayor frecuencia en animales jóvenes, y 
an obligate intracellular parasite of the intestinal mucosa, leading (in some cases) to massive cell destruction of the large intestine, causing the malabsorption syndrome $(7,8)$. The bovine cryptosporidiosis is a protozoal disease caused by Cryptosporidium, Tyzzer 1907, and it infects animals regardless of sex, age, or type that may or may not demonstrate clinical signs, but often causing great economic losses (9). Infected hosts eliminate the infective form of the parasite, called oocysts, in their feces, contaminating the environment, food and/or water. Thus, susceptible animals become infected through oocyst ingestion or inhalation (10). Giardia spp., Kunstler 1882, is considered one of the most important intestinal parasite of humans and animals, usually associated to the occurrence of diarrhea. This protozoan may be involved in the onset of neonatal diarrhea, independently or associated with other endoparasites (11).

Therefore, as noted above, protozoal infections in domestic animals lead to severe health problems, in addition to economic losses to producers. Thus, the aim of this study was to evaluate the occurrence of infections caused by Cryptosporidium, Giardia and Eimeria in calves with or without diarrhea, as well as identify potential risk factors for infection.

\section{MATERIALS AND METHDS}

Local and animals. This study was carried out in 43 dairy farms located in the Western region of Santa Catarina State, Southern Brazil. Fecal samples $(n=243)$ of female calves, aging from one to 60 days were randomly collected regardless of race, type of environment, or animal management. On average, five grams of feces were collected aseptically (using latex gloves) from each calf with or without diarrhea, properly stored on ice, transported to the laboratory, and kept at $5^{\circ} \mathrm{C}$ until analyses.

Parasitological examination. In order to visualize the presence of parasites in fecal samples, the centrifugal flotation technique was used. Briefly, saturated sugar solution was mixed with 2 grams of feces, in order to cause cysts and oocysts flotation (7). Once homogenized, filtration was performed using a plastic sieve, and the material filtered was allocated in Falcon tubes. Then, the tube was filled up with sugar solution to form a meniscus, covered by a glass coverslip, and centrifugated at 2000 rpm by 5 minutes. The coverslip was removed and placed on a glass slide, with a drop of lugol diluted in distilled water $(1 \mathrm{v} / \mathrm{v})$ for microscope observation (7). Although it is a qualitative technique, some authors have used this methodology to determine the degree of parasitic infection as follow: mild esta enfermedad está caracterizada producir diarrea o disentería, lo cual está relacionado con pérdidas económicas significativas ocasionadas por las altas tasas de morbilidad y mortalidad y con un aumento en los costos de prevención y tratamiento (6). Eimeria es un parásito intracelular obligado de la mucosa intestinal, lo que lleva (en algunos casos) a la destrucción masiva del intestino grueso, generando el síndrome de malabsorción $(7,8)$. La criptosporidiosis bovina es una enfermedad protozoaria causada por Cryptosporidium, Tyzzer 1907, que infecta a los animales sin importar su sexo, edad o tipo, los cuales pueden o no presentar signos clínicos, pero que con frecuencia causa grandes pérdidas económicas (9). Los hospedadores infectados eliminan la forma infecciosa del parásito, denominada oocistos, en sus heces, contaminando al ambiente, a los alimentos y / o al agua. Por lo tanto, los animales susceptibles se infectan a través de la ingesta o inhalación de oocistos (10). Giardia spp., Kunstler 1882, es considerado uno de los parásitos intestinales más importantes presentes en seres humanos y animales, el cual generalmente se asocia a la aparición de diarrea. Este protozoario puede estar implicado en el inicio de la diarrea neonatal, de manera independiente o asociado con otros endoparásitos (11).

Por lo tanto, como se señaló anteriormente, las infecciones por protozoos en animales domésticos conducen a graves problemas de salud, sumado a pérdidas económicas para los productores. Así, el objetivo de este estudio fue evaluar la ocurrencia de infecciones causadas por Cryptosporidium, Giardia y Eimeria en terneros con o sin diarrea, como también identificar los posibles factores de riesgo de infección.

\section{MATERIALES Y MÉTODOS}

Lugar y animales. Este estudio se llevó a cabo en 43 granjas lecheras ubicadas en la región occidental del estado de Santa Catarina en el sur de Brasil. Se recolectaron muestras fecales $(n=243)$ de terneras en edades de uno a 60 días aleatoriamente, independientemente de su raza, tipo de entorno o del tipo de manejo dado a los animales. Se recolectaron en promedio cinco gramos de heces de cada becerro con o sin diarrea, se almacenaron apropiadamente con hielo, fueron transportados hasta el laboratorio y se mantuvieron a $5^{\circ} \mathrm{C}$ hasta el momento del análisis.

Examen parasitológico. Se utilizó la técnica de flotación centrífuga con el fin de visualizar la presencia de parásitos en las muestras fecales La solución de azúcar saturado se mezcló con 2 gramos de heces, con el fin de causar quistes y flotación de 
(from 1 to 100 cysts/oocysts), moderate (from 101 to 300 cysts/oocysts) and severe (more than 301 cysts/oocysts) (12). In fecal samples with the presence of helminth's eggs, it was performed culture for individual larvae assessment for genus identification.

Epidemiological survey. Farm and animal information were obtained throughout the application of a questionnaire to the farmers. This information was crosschecked with the results on fecal examination, in order to identify the risk factors for cryptosporidiosis, giardiasis and eimeriosis. The following questions were asked: type of feeding (cow's milk, artificial milk, concentrate, milk and concentrate, milk, concentrate and hay); housing (individual or collective); type of bedding (concrete, slatted, soil or concrete/slatted); cleaning interval (1-7, $8-15$ or >15 days); milk supply (bottle, bucket, both, or milk was not provided); contact time with the cow ( $<1,1-5$ or $>5$ hours); water source (well or fountain); contact with rats (yes or no); contact with dogs (yes or no); contact with cats (yes or no); contact with chickens (yes or no); presence of flies (yes or no); animal age (1-15, $16-30,31-45$ or $\geq 46$ days); race (Holstein, Jersey, or crossbreed) and fecal consistency (normal or diarrhearic).

Statistical analysis. The data generated from the interviews (independent variables) and parasite identification - Giardia, Cryptosporidium and Eimeria (response variable) were recorded and analyzed by R-language, v.3.1.1 (R Development Core Team, 2012). Cross tabulation and descriptive statistics, such as frequency and percentage, were performed on all independent variables. Independent variables (Table 1, 2 and 3) were first screened based on all the response variable (Giardia, Cryptosporidium and Eimeria). Variables with large amounts of missing data ( $>10 \%)$ and limited variability $(<20 \%)$ were not included in the multivariable model. The remaining variables were individually accounted into an unvariable logistic regression model (chi-square test). Under the assumption that each animal is clustered in a herd, a mixed model was performed using the farm random-effect, due to the lack of independency among samples from animals in the same farm. Univariate analysis was first conducted using all the fourteen pre-selected variables. Subsequently, each variable with $P \leq 0.15$ was selected for inclusion in the multivariable analysis. It was build one final model for each outcome of interest individually for Giardia, Cryptosporidium and one for Eimeria. Variance inflation factor (VIF) was estimated to verify the relation between all selected independent variables to check for potential collinearity, in which coefficient $>2.50$ was considered high. If a high VIF was found, the variable with lower oocistos (7). Una vez homogeneizada la mezcla, se realizó una filtración utilizando un tamiz de plástico, y el material filtrado se repartió en tubos Falcon. A continuación, se llenó el tubo con una solución de azúcar para formar un menisco, se cubrió con un cubreobjetos de vidrio y se centrifugó a 2000 rpm durante 5 minutos. Se retiró el cubreobjetos y se colocó sobre una lámina de vidrio con una gota de lugol diluida en agua destilada (1v/v) para ser observada bajo el microscopio (7). A pesar de ser una técnica cualitativa, algunos autores han utilizado esta metodología para determinar el grado de infección parasitaria de la siguiente manera: leve (de 1 a 100 quistes/oocistos), moderada (de 101 a 300 quistes/ooquistes) y grave (más de 301 quistes/ooquistes) (12). Se realizó un cultivo en las muestras fecales con presencia de huevos de helmintos para determinar la identificación de género de las larvas individuales.

Encuesta epidemiológica. La información sobre granjas y animales se obtuvo por medio de un cuestionario diligenciado por los granjeros. Se realizó una verificación cruzada de la información con los resultados del examen fecal con el fin de identificar los factores de riesgo para la criptosporidiosis, la giardiasis y la eimeriosis. Se plantearon preguntas acerca de los siguientes factores: tipo de alimentación (leche de vaca, leche artificial, concentrado, leche y concentrado, leche, concentrado y heno); tipo de albergue (individual o colectivo); tipo de lecho (de hormigón, de listones, de tierra o de hormigón/listones); periodicidad de limpieza (1-7, 8-15 o > 15 días); suministro de leche (en botella, cubo, ambos o no se proporcionó leche); tiempo de contacto con la vaca ( $<1,1-5$ o $>$ 5 horas); fuente de agua (pozo o fuente); contacto con ratas (sí o no); contacto con perros (sí o no); contacto con gatos (sí o no); contacto con pollos (sí o no); presencia de moscas (sí o no); edad del animal (1-15, 16-30, 31-45 o $\geq 46$ días); raza (Holstein, Jersey o cruzada) y consistencia fecal (normal o diarreica).

Análisis estadístico. Los datos generados por medio de las entrevistas (variables independientes) y la identificación de parásitos - Giardia, Cryptosporidium y Eimeria (variable de respuesta) fueron registrados y analizados con el software R-language, v.3.1.1 (R Development Core Team, 2012). Se aplicó una tabulación cruzada y un análisis de estadística descriptiva, como frecuencia y porcentaje, en todas las variables independientes. La primera selección de variables independientes (Tablas 1, 2 y 3) se llevó a cabo con base en todas las variables de respuesta (Giardia, Cryptosporidium y Eimeria). Las variables con grandes cantidades de datos faltantes (>10\%) y variabilidad limitada $(<20 \%)$ no se incluyeron en el modelo multivariable. Las variables restantes 
p-value was considered for the multivariable model. A crude relative risk (RR) was applied to assess the impact of individual factors on the outcomes. Furthermore, selected variables, when considering Cryptosporidium as an outcome $(n=8)$, were included in the multivariable model (feeding, housing, time with the cow, water source, contact with rats, contact with dogs, presence of flies, and age). When the outcome was Giardia $(n=6)$, it was included in the multivariable model (feed, milk supply, time with the cow, water source, contact with dogs, and age) and finally when the outcome was Eimeria $(n=2)$, it was included in the multivariable model (bedding type and age).

A second univariate model was built in order to verify the presence of an effect-cause situation. As outcome variable, it was considered the presence of any protozoan (Giardia, Cryptosporidium or Eimeria) and fecal consistence (regular or presence of diarrhea) as the predicted variable. For this model a $\mathrm{P} \leq 0.05$ was considered significant associated.

Multivariate models were built in a manual forward method, where each remaining variable was added to the best previous model selected by the Akaike Information Criterion (AIC). A backward elimination step was used, resulting on a final model in which only variables with $p \leq 0.05$ were retained. Confounding effects were investigated by checking changes in the point estimate of each variable that remained in the model. Changes in parameter estimated as $>25 \%$ were considered a confounder factor, and it was kept in the model until the final model, and finally two-way interaction term between variables with biological plausibility were investigated. We used deviance perform as a goodness of fit test for overall model.

\section{RESULTS}

Among all fecal samples examinated, $46.50 \%$ $(113 / 243)$ were protozoa negative, while the other samples $(53.50 \% ; 130 / 243)$ were positives for one or more parasites. The percentage of calves infected by Cryptosporidium spp. was $20.99 \%$ (51/243); by Giardia spp. $26.75 \%$ $(65 / 243)$; and by Eimeria spp. $21.81 \%$ $(53 / 243)$ (Figure $1 \mathrm{~A})$. Out of 243 samples, 95 $(46.50 \%)$ showed a single protozoan infection (Figure 1B), while $35(14.40 \%)$ had mixed infection caused by two or three protozoa. Among the mixed infections, the association of Cryptosporidium spp and Giardia spp was the most common ( $6.99 \%$, or $17 / 243$ calves), followed by Eimeria spp and Cryptosporidium spp ( $2.88 \%$, or $7 / 243$ calves), and Giardia spp associated with Eimeria spp $(2.06 \%, 6 / 243$ calves). The mixed infection caused by all three se contabilizaron individualmente en un modelo de regresión logística univariable (prueba de chicuadrado). Bajo el supuesto de que cada animal se agrupa en un rebaño, se aplicó un modelo mixto utilizando el efecto aleatorio de la finca, debido a la falta de independencia entre las muestras de animales de la misma finca. Se realizó por primera vez un análisis univariable utilizando las catorce variables preseleccionadas. Posteriormente, cada variable con un valor de $p \leq 0.15$ fue seleccionada para ser incluida en el análisis multivariable. Se creó un modelo final de cada resultado de interés en Giardia, Cryptosporidium y Eimeria individualmente. Se estimó el factor de inflación de la varianza (FIV) para verificar la relación entre todas las variables independientes que fueron seleccionadas para examinar una potencial colinealidad, en donde el coeficiente $>2,50$ es considerado alto. En caso de haber un FIV alto, la variable con el menor valor $\mathrm{p}$ se fue aplicada en el modelo multivariable. Se aplicó el riesgo relativo bruto (RR) para evaluar el impacto de los factores individuales sobre los resultados. Además, en el modelo multivariable se incluyeron variables seleccionadas (alimentación, vivienda, tiempo con la vaca, fuente de agua, contacto con ratas, contacto con perros, presencia de moscas y edad) , en donde la aparición de Cryptosporidium es considerada como un resultado $(n=8))$. Cuando el resultado mostró Giardia $(n=6)$, se incluyó en el modelo multivariable (alimentación, suministro de leche, tiempo con la vaca, fuente de agua, contacto con perros y edad) y, por último, cuando el resultado mostró Eimeria $(n=2)$, se incluyó en el modelo multivariable (tipo de lecho y edad).

Se construyó un segundo modelo univariante para verificar la presencia de una situación de efectocausa. La presencia de cualquier protozoario ( Giardia, Cryptosporidium o Eimeria ) y la consistencia fecal (normal o presencia de diarrea) fueron consideradas la variable predicha. Un valor de $P \leq 0,05$ fue considerado significativo en este model.

Los modelos multivariados se construyeron a través de un método de avance manual, en donde cada variable restante se sumó al mejor modelo anterior, seleccionado mediante el Criterio de Información Alcalina (CIA). Se utilizó un paso atrás de eliminación, lo que dio como resultado un modelo final en el que sólo se conservaron variables con valores de $p \leq 0.05$. Los efectos de confusión fueron investigados por medio de un monitoreo de los cambios en la estimación puntual de cada variable que permaneció en el modelo. Los cambios observados en el parámetro estimado como $>25 \%$ fueron considerados un factor de confusión y se mantuvo hasta el modelo final, y por último 
protozoa represented $2.40 \%$ (5/243 calves).

The degree of infection by Cryptosporidium spp, Giardia spp, and Eimeria spp was rated as mild, moderate and high, respectively (Figure $1 \mathrm{C}$ ). We found all three levels of infection caused by Eimeria spp and Giardia spp, differently to Cryptosporidium spp that did not cause severe infection. The mild type of infection was the most frequently observed type for the three protozoa (Figure 1C).

Diarrhea was observed on $25.51 \%$ of the calves, where only $13.17 \%$ were positive for at least one protozoa. Thus, $74.49 \%$ did not have diarrhea, though $40.33 \%$ of calves were affected by one of the investigated protozoa. Moreover, the cause-effect analyses did not find significant association between the presence
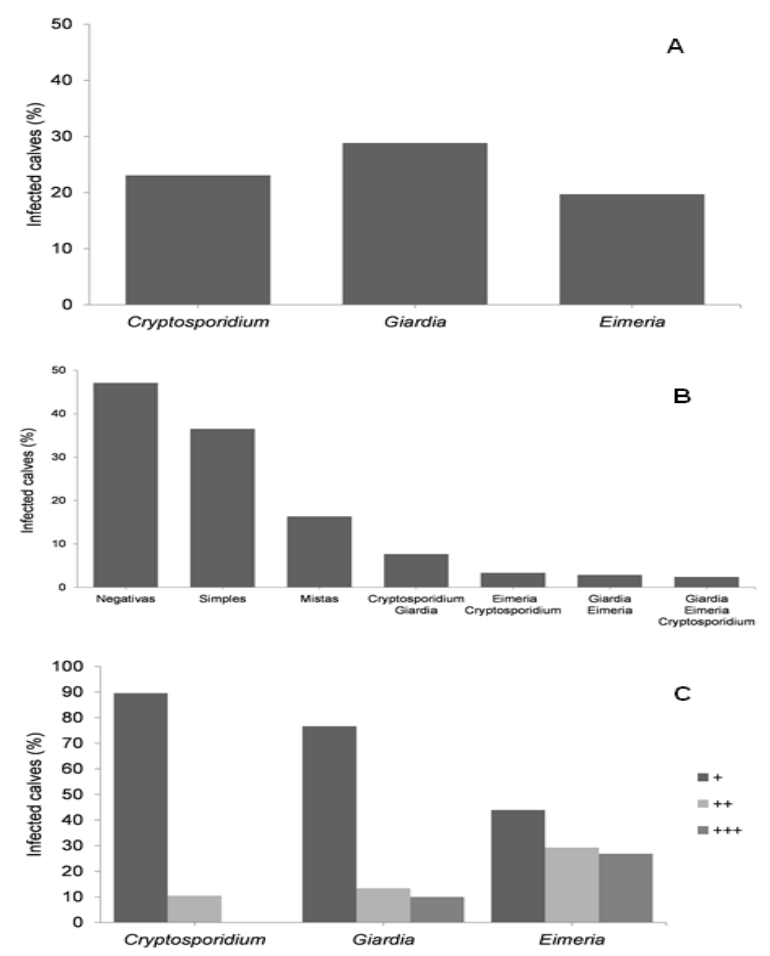

Figure 1. [A] Percentage of calves infected by Cryptosporidium spp. (51/243), Giardia spp. (65/243) and Eimeria spp. (53/243) in different cities of the Western Santa Catarina State. [B] Sample distribution - percentage of animals with negative parasitological results, animals with simple and mixed infections, in addition to the percentage of positive animals by each parasite type involved in mixed infections of calves $(n=243)$ in several municipalities of Western Santa Catarina State. [C] Percentage of samples positives according to the degree of infection [mild $(+)$, moderate $(++)$ or high $(+++)$ ] caused by Cryptosporidium spp. (51/100\%), Giardia spp. (65/100\%), and Eimeria spp. $(53 / 100 \%)$ in calves. se investigó la interacción en dos vías entre variables con plausibilidad biológica. Utilizamos la desviación para realizar una prueba de bondad de ajuste del modelo general.

\section{RESULTADOS}

Entre todas las muestras fecales examinadas, el $46.50 \%$ (113/243) dieron resultados negativos para protozoarios, mientras que las demás muestras (53.50\%; 130/243) dieron resultados positivos para uno o más parásitos. El porcentaje de terneros infectados por Cryptosporidium spp. fue del 20.99\% (51/243); por Giardia spp. del $26.75 \%$ (65/243); y por Eimeria spp. del $21.81 \%$ (53/243) (Figura 1A). De las 243 muestras, 95 (46.50\%) mostraron una única infección por protozoarios (Figura 1B), mientras que 35 (14.40\%) presentaron una infección mixta causada por dos o tres protozoarios. Entre las infecciones mixtas, la asociación entre Cryptosporidium spp y Giardia spp fue la más común (6.99\% o 17/243 terneros), seguida de Eimeria spp y Cryptosporidium spp (2.88\% o 7/243 terneros), y por último Giardia spp y Eimeria spp (2.06\%, 6/243 terneros). La infección mixta causada por los tres protozoarios a la vez representó el $2.40 \%$ (5/243 terneros).

El grado de infección por Cryptosporidium spp, Giardia spp y Eimeria spp fue clasificado como leve, moderado y alto, respectivamente (Figura 1C). Encontramos que los tres niveles de infección son causados por Eimeria spp y Giardia spp, a diferencia de Cryptosporidium spp que no causó infección grave. La infección leve fue el tipo de infección observado con mayor frecuencia en los tres protozoarios (Figura 1C).

Se observó diarrea en el $25.51 \%$ de los terneros, en donde únicamente el $13.17 \%$ mostró resultados positivos de al menos un protozoo. Así, el $74.49 \%$ no presentó diarrea, aunque el $40.33 \%$ de los terneros se vieron afectados por uno de los protozoarios bajo estudio. Además, los análisis de causa-efecto no mostraron una asociación significativa entre la presencia de Cryptosporidium spp, Giardia spp y Eimeria spp y la consistencia fecal $(p>0.05)$. Se encontró que el $4.12 \%(10 / 243)$ de las muestras fecales traían también huevos de parásitos de la familia Trichostrongylidae, que corresponden a Haemonchus spp. y Trichostrongylus spp.

Los resultados del análisis univariado de los factores de riesgo de infección por Cryptosporidium spp, Giardia spp. Y Eimeria spp. Se muestran en las tablas 1, 2 y 3, respectivamente. Para el género Cryptosporidium, se encontró que la vivienda colectiva, sumada a períodos de tiempo más largos junto a su madre después del nacimiento, y el contacto directo con perros y gatos, aumenta la 
of Cryptosporidium spp, Giardia spp and Eimeria spp and fecal consistency $(p>0.05)$. It was found that $4.12 \%(10 / 243)$ of the fecal samples also had eggs of parasites from the Trichostrongylidae family, corresponding to Haemonchus spp. and Trichostrongylus spp.

The results of univariate analysis for risk factors for infection by Cryptosporidium spp, Giardia spp. and Eimeria spp. are shown in table 1, 2 and 3, respectively. For the Cryptosporidium genus, it was found that collective housing, along with longer periods of time with its mother after birth, and direct contact with dogs and cats, increases the chance of infection to calves. For Giardia spp, the main factors for infection were: not supplying milk, sources of water intake, contact with dogs, and animals age between 31 and 45 days old. For Eimeria spp, two risk factors were observed in the univariate analysis: age and pens with concrete and slatted floors.

The results of risk factors for Cryptosporidium spp, Giardia spp and Eimeria spp infection on the multivariate analysis are shown in Table 4. We found that calves fed with concentrate had, on average, 37 times higher risk to be infected compared to those fed with cow's milk, contrasting to artificial milk that showed 9.91 times more risk (Table 4). Similarly, calves on a diet of milk/concentrate and milk/ concentrate/hay were 9.80 and 4.79 times more likely to be infected by these protozoans, respectively. However, the period of time that calves had direct contact with their mothers, immediately after birth ( 1 to 5 hours, and more than 5 hours) increased the risk of infection by Cryptosporidium spp in 0.15 and 0.30 times, respectively. Contact with dogs increased the relative risk of infection by Cryptosporidium spp in 3.57 times. For the presence of Giardia spp., a single variable was identified as a risk factor by the multivariate analysis: milk source. Both forms of supply (bottle and bucket) increased their risk on 5.40 times. Regarding the risk factors for Eimeria spp infection, we noticed that concrete and slatted floors were three times more risky for infections compared to concrete floors. The animal age was also significantly associated with the occurrence of Eimeria spp, since we noticed that animals with more than 15 days of age had more chances of infection.

\section{DISCUSSION}

In this study, a higher number of calves up to 60 days of age were infected by Giardia spp. However, on a similar study conducted in probabilidad de infección en terneros. Para Giardia spp, los principales factores de infección fueron: el no suministrar leche, las fuentes de ingesta de agua, el contacto con perros y animales con edades entre 31 y 45 días. Para Eimeria spp, se observaron dos factores de riesgo en el análisis univariado: edad y establos con pisos de hormigón y listones.

Los resultados de los factores de riesgo de Cryptosporidium spp, Giardia spp y Eimeria spp en el análisis multivariado se muestran en la Tabla 4. Se encontró que los terneros alimentados con concentrado tuvieron en promedio un riesgo de infección 37 veces mayor que los terneros alimentados con leche de vaca, en contraste con la leche artificial que mostró un riesgo 9.91 veces más alto (Tabla 4). Del mismo modo, los terneros alimentados con una dieta a base de leche/ concentrado y leche/concentrado/heno tuvieron una probabilidad 9.80 y 4.79 veces mayor de ser infectados por estos protozoos, respectivamente. Sin embargo, se observó que el tiempo durante el cual los terneros tuvieron contacto directo con sus madres, inmediatamente después de nacer (1 a 5 horas y más de 5 horas), aumentó el riesgo de infección por Cryptosporidium spp en 0.15 y 0.30 veces, respectivamente. El contacto con perros aumentó 3.57 veces el riesgo relativo de infección por Cryptosporidium spp. En cuanto a la presencia de Giardia spp., el análisis multivariado identificó una única variable como factor de riesgo: la fuente de leche. Ambas formas de suministro (botella y cubo) aumentaron el riesgo en 5.40 veces. En cuanto a los factores de riesgo de la infección por Eimeria spp, pudimos observar que los pisos fabricados con hormigón y listones presentaron un riesgo de infección tres veces mayor que los pisos de concreto. La edad de los animales también estuvo asociada significativamente con la aparición de Eimeria spp, ya que se observó que los animales mayores a 15 días de edad tuvieron mayores posibilidades de infección.

\section{DISCUSIÓN}

En el presente estudio, una mayor cantidad de terneros de hasta 60 días de edad fueron infectados por Giardia spp. Sin embargo, en un estudio similar realizado en Brasil se observó una prevalencia inferior (26.75\%). Según la literatura, se han observado quistes de Giardia spp. en 9\% de 120 muestras fecales tomadas de terneros con edades de 1 a 90 días (11). Además, otro estudio realizado en 560 terneros mostró una positividad del 17\% (95) de Giardia spp. (13). El índice de animales positivos en este estudio fue similar a la tasa media mundial (25.56\%) de terneros que pierden Giardia duodenale (14). Según el análisis multivariado, la leche de vaca suministrada por botella y cubo aumentó las posibilidades de infección por Giardia 
Table 1. Univariate analysis of risk factors for Cryptosporidium infection in calves.

\begin{tabular}{|c|c|c|c|c|}
\hline Variables & No. & Frequency (\%) Median & $P$ - value & RR (CI: 95\%) \\
\hline \multicolumn{5}{|l|}{ Cryptosporidium } \\
\hline Feed & 239 & & & \\
\hline 1. Cow's milk & & $12(5)$ & - & - \\
\hline 2. Artificial milk & & $14(6)$ & 0.21 & $4.65(0.39-54.27)$ \\
\hline 3. Concentrate & & $12(5)$ & 0.09 & $8.19(0.70-94.59)$ \\
\hline 4. Milk + concentrate & & $85(36)$ & 0.19 & $4.32(0.48-38.70)$ \\
\hline 5. Milk + concentrate + hay & & $116(48)$ & 0.51 & $2.06(0.23-18.18)$ \\
\hline Housing & 239 & & & \\
\hline 1. Individual & & $131(55)$ & - & - \\
\hline 2. Grouped & & $108(45)$ & $<0.001$ & $1.15(1.01-3.01)$ \\
\hline Floor & 239 & & & \\
\hline 1. Concrete & & $34(14)$ & - & - \\
\hline 2. Slatted & & $109(45)$ & 0.23 & $0.54(0.18-0.99)$ \\
\hline 3. Ground & & $56(23)$ & 0.74 & $0.83(0.29-2.40)$ \\
\hline 4. Concrete + slatted & & $39(16)$ & 0.06 & $0.29(0.08-1.09)$ \\
\hline Cleaning interval & 239 & & & \\
\hline 1. 1-7 days & & $59(33)$ & - & - \\
\hline 2. $8-15$ days & & $6(3)$ & 0.88 & $0.20(0.29-2.80)$ \\
\hline 4. $>15$ days & & $111(64)$ & 0.70 & $0.54(0.01-0.89)$ \\
\hline Supply milk & 239 & & & \\
\hline 1. Bottle & & $78(52)$ & - & - \\
\hline 2. Bucket & & $6(4)$ & 0.54 & $0.54(0.001-1.00)$ \\
\hline 3. Bottle and bucket & & $50(33)$ & 0.47 & $0.87(0.30-2.58)$ \\
\hline 4. Without milk supply & & $16(11)$ & 0.57 & $0.94(0.10-5.21)$ \\
\hline Time with the cow & 239 & & & \\
\hline 1. $<1$ hour & & $118(50)$ & - & - \\
\hline 2. $1-5$ hours & & $36(15)$ & 0.05 & $0.24(0.05-1.00)$ \\
\hline 3. $>5$ hours & & $85(35)$ & 0.57 & $0.78(0.33-1.83)$ \\
\hline Water source & 239 & & & \\
\hline 1. Artesian Well & & $109(46)$ & - & - \\
\hline 2. Fount & & $130(54)$ & 0.13 & $1.94(0.81-4.67)$ \\
\hline Contact with rats & 239 & & & \\
\hline No & & $38(16)$ & - & - \\
\hline Yes & & $201(84)$ & 0.66 & $1.44(0.49-4.21)$ \\
\hline Contact with dogs & 239 & & & \\
\hline No & & $139(58)$ & - & - \\
\hline Yes & & $100(42)$ & 0.03 & $2.33(1.04-5.22)$ \\
\hline Contact with cats & 239 & & & \\
\hline No & & $66(28)$ & - & - \\
\hline Yes & & $173(72)$ & 0.03 & $2.44(1.05-4.21)$ \\
\hline Contact with thicken & 239 & & & \\
\hline No & & $185(78)$ & - & - \\
\hline Yes & & $54(22)$ & 0.49 & $1.27(0.48-3.32)$ \\
\hline Fly presence & 239 & & & \\
\hline Low & & $86(36)$ & - & - \\
\hline Moderate & & $69(30)$ & 0.22 & $1.03(0.18-1.49)$ \\
\hline High & & $84(35)$ & 0.13 & $0.40(0.12-1.33)$ \\
\hline Age & 239 & & & \\
\hline 1. $1-15$ days & & $54(22)$ & - & - \\
\hline 2. $16-30$ days & & $61(25)$ & 0.15 & $2.04(0.76-5.47)$ \\
\hline 3. $31-45$ days & & $43(18)$ & 0.48 & $1.50(0.47-4.74)$ \\
\hline 4. $>46$ days & & $84(35)$ & 0.24 & $1.80(0.66-4.86)$ \\
\hline Breed & 239 & & & \\
\hline 1. Holstein & & $195(80)$ & - & - \\
\hline 2. Jersey & & $30(12)$ & 0.27 & $1.44(0.53-3.85)$ \\
\hline 3. Crossbreed & & $17(8)$ & 0.78 & $2.19(0.65-7.30)$ \\
\hline
\end{tabular}


Table 2. Univariate analysis of risk factors for Giardia infection in calves.

\begin{tabular}{|c|c|c|c|c|}
\hline Variables & No. & Frequency $(\%)$ Median & $P$ - value & RR (CI: 95\%) \\
\hline \multicolumn{5}{|l|}{ Giardia } \\
\hline Feed & 239 & & & \\
\hline 1. Cow's milk & & $12(5)$ & - & - \\
\hline 2. Artificial milk & & $14(6)$ & 0.49 & $0.46(0.05-4.14)$ \\
\hline 3. Concentrate & & $12(5)$ & 0.06 & $6.42(0.87-47.02)$ \\
\hline 4. Milk + concentrate & & $85(36)$ & 0.91 & $0.91(0.19-4.42)$ \\
\hline 5. Milk + concentrate + hay & & $116(48)$ & 0.81 & $1.19(0.25-5.58)$ \\
\hline Housing & 239 & & & \\
\hline 1. Individual & & $131(55)$ & - & - \\
\hline 2. Grouped & & $108(45)$ & 0.55 & $0.80(0.33-1.66)$ \\
\hline Floor & 239 & & & \\
\hline 1. Concrete & & $35(14)$ & - & - \\
\hline 2. Slatted & & $109(45)$ & 0.78 & $1.16(0.39-3.44)$ \\
\hline 3. Ground & & $56(23)$ & 0.26 & $0.49(0.14-1.69)$ \\
\hline 4. Concrete + slatted & & $39(16)$ & 0.92 & $0.93(0.25-3.44)$ \\
\hline Cleaning interval & 239 & & & \\
\hline 1. 1-7 days & & $59(33)$ & - & - \\
\hline 2. 8-15 days & & $6(3)$ & 0.47 & $2.09(0.28-15.67)$ \\
\hline 4. > 15 days & & $111(64)$ & 0.55 & $0.20(0.20-1.49)$ \\
\hline Supply milk & 239 & & & \\
\hline 1. Bottle & & $78(52)$ & - & - \\
\hline 2. Bucket & & $6(4)$ & 1 & $2.47(0.001-65.00)$ \\
\hline 3. Bottle + bucket & & $50(33)$ & 0.36 & $1.47(0.63-3.44)$ \\
\hline 4. Without milk supply & & $16(11)$ & 0.003 & $5.40(1.73-16.83)$ \\
\hline Time with the cow & 239 & & & \\
\hline 1. $<1$ hour & & $118(50)$ & - & - \\
\hline 2. $1-5$ hours & & $36(15)$ & 0.07 & $2.54(0.91-7.05)$ \\
\hline 3. $>5$ hours & & $85(35)$ & 0.19 & $1.76(0.75-4.11)$ \\
\hline Water source & 239 & & & \\
\hline 1. Artesian Well & & $109(46)$ & - & - \\
\hline 2. Fount & & $130(54)$ & 0.05 & $2.15(0.97-4.78)$ \\
\hline Contact with rats & 239 & & & \\
\hline No & & $38(16)$ & - & - \\
\hline Yes & & $201(84)$ & 0.66 & $0.81(0.31-2.09)$ \\
\hline Contact with dogs & 239 & & & \\
\hline No & & $139(58)$ & - & - \\
\hline Yes & & $100(42)$ & 0.05 & $2.10(1.00-4.49)$ \\
\hline Contact with cats & 239 & & & \\
\hline No & & $66(28)$ & - & - \\
\hline Yes & & $173(72)$ & 0.24 & $1.71(0.69-4.21)$ \\
\hline Contact with chickens & 239 & & & \\
\hline No & & $185(78)$ & - & - \\
\hline Yes & & $54(22)$ & 0.98 & $1.63(0.61-4.37)$ \\
\hline Presence of flies & 239 & & & \\
\hline Low & & $86(36)$ & - & - \\
\hline Moderate & & $69(30)$ & 0.93 & $1.03(0.43-2.47)$ \\
\hline High & & $84(35)$ & 0.19 & $0.53(0.20-1.36)$ \\
\hline Age & 239 & & & \\
\hline 1. 1-15 days & & $54(22)$ & - & - \\
\hline 2. $16-30$ days & & $61(25)$ & 0.58 & $0.78(0.33-1.84)$ \\
\hline 3. $31-45$ days & & $43(18)$ & 0.04 & $0.35(0.12-0.99)$ \\
\hline 4. $>46$ days & & $84(35)$ & 0.19 & $0.56(0.24-1.33)$ \\
\hline Breed & 239 & & & \\
\hline 1. Holstein & & $195(80)$ & - & - \\
\hline 2. Jersey & & $30(12)$ & 0.46 & $1.44(0.53-3.85)$ \\
\hline 3. Crossbreed & & $17(8)$ & 0.20 & $2.19(0.65-7.30)$ \\
\hline
\end{tabular}


Table 3. Univariate analysis of risk factors for Eimeria infection in calves.

\begin{tabular}{|c|c|c|c|c|}
\hline Variables & No. & Frequency (\%) Median & $P$ - value & RR (CI: 95\%) \\
\hline \multicolumn{5}{|l|}{ Eimeria } \\
\hline Feed & 239 & & & \\
\hline 1. Cow's milk & & $12(5)$ & - & - \\
\hline 2. Artificial milk & & $14(6)$ & 0.75 & $1.66(0.06-40.56)$ \\
\hline 3. Concentrate & & $12(5)$ & 0.44 & $3.70(0.13-104.91)$ \\
\hline 4. Milk + concentrate & & $85(36)$ & 0.38 & $3.23(0.23-45.82)$ \\
\hline 5. Milk + concentrate + hay & & $116(48)$ & 0.50 & $2.42(0.17-33.80)$ \\
\hline Housing & 239 & & & \\
\hline 1. Individual & & $131(55)$ & - & - \\
\hline 2. Grouped & & $108(45)$ & 0.14 & $2.16(0.76-6.14)$ \\
\hline Floor & 239 & & & \\
\hline 1. Concrete & & $35(14)$ & - & - \\
\hline 2. Slatted & & $109(45)$ & 0.20 & $0.42(0.11-1.57)$ \\
\hline 3. Ground & & $56(23)$ & 0.58 & $1.44(0.38-5.47)$ \\
\hline 4. Concrete + slatted & & $39(16)$ & 0.03 & $0.06(0.004-0.86)$ \\
\hline Cleaning interval & 239 & & & \\
\hline 1. 1-7 days & & $59(33)$ & - & - \\
\hline 2. 8-15 days & & $6(3)$ & 0.85 & $0.75(0.03-14.54)$ \\
\hline 4. $>15$ days & & $111(64)$ & 0.63 & $0.70(0.16-2.97)$ \\
\hline Supply milk & 239 & & & \\
\hline 1. Bottle & & $78(52)$ & - & - \\
\hline 2. Bucket & & $6(4)$ & 0.19 & $7.75(0.33-177.09)$ \\
\hline 3. Bottle + bucket & & $50(33)$ & 0.97 & $1.04(0.07-14.71)$ \\
\hline 4. Without milk supply & & $16(11)$ & 0.85 & $0.74(0.03-16.38)$ \\
\hline Time with the cow & 239 & & & \\
\hline 1. $<1$ hour & & $118(50)$ & - & - \\
\hline 2. 1-5 hours & & $36(15)$ & 0.42 & $0.48(0.08-2.86)$ \\
\hline 3. $>5$ hours & & $85(35)$ & 0.78 & $0.82(0.21-3.12)$ \\
\hline Water source & 239 & & & \\
\hline 1. Artesian well & & $109(46)$ & - & - \\
\hline 2. Fount & & $130(54)$ & 0.45 & $1.61(0.45-5.69)$ \\
\hline Contact with rats & 239 & & & \\
\hline No & & $38(16)$ & - & - \\
\hline Yes & & $201(84)$ & 0.21 & $2.58(0.56-11.78)$ \\
\hline Contact with dogs & 239 & & & \\
\hline No & & $139(58)$ & - & - \\
\hline Yes & & $100(42)$ & 0.56 & $1.41(0.42-4.73)$ \\
\hline Contact with cats & 239 & & & \\
\hline No & & $66(28)$ & - & - \\
\hline Yes & & $173(72)$ & 0.70 & $0.70(0.20-2.90)$ \\
\hline Contact with chickens & 239 & & & \\
\hline No & & $185(78)$ & - & - \\
\hline Yes & & $54(22)$ & 0.42 & $0.52(0.10-2.53)$ \\
\hline Presence of flies & 239 & & & \\
\hline Low & & $86(36)$ & - & - \\
\hline Moderate & & $69(30)$ & 0.37 & $1.87(0.46-7.51)$ \\
\hline High & & $84(35)$ & 0.92 & $1.07(0.23-4.92)$ \\
\hline Age & 239 & & & \\
\hline 1. $1-15$ days & & $54(22)$ & - & - \\
\hline 2. $16-30$ days & & $61(25)$ & 0.02 & $6.22(1.33-29.08)$ \\
\hline 3. $31-45$ days & & $43(18)$ & 0.001 & $10.63(2.37-47.53)$ \\
\hline 4. $>46$ days & & $84(35)$ & 0.001 & $11.94(2.53-56.17)$ \\
\hline Breed & 239 & & & \\
\hline 1. Holstein & & $195(80)$ & - & - \\
\hline 2. Jersey & & $30(12)$ & 0.30 & $1.81(0.57-5.69)$ \\
\hline 3. Crossbreed & & $17(8)$ & 0.55 & $1.59(0.33-7.52)$ \\
\hline
\end{tabular}


Table 4. Multivariate analysis of risk factors for Cryptosporidium, Giardia and Eimeria infection in calves.

\begin{tabular}{|c|c|c|c|}
\hline Variables & Estimate $(\beta)$ & $P$ - value & RR (CI: 95\%) \\
\hline \multicolumn{4}{|l|}{ Cryptosporidium } \\
\hline \multicolumn{4}{|l|}{ Feed } \\
\hline 1. Cow's milk & - & - & - \\
\hline 2. Artificial milk & 2.29 & 0.07 & $9.91(7.76-12.65)$ \\
\hline 3. Concentrate & 3.63 & 0.006 & $37.92(17.28-83.20)$ \\
\hline 4. Milk + concentrate & 2.28 & 0.04 & $9.80(7.68-12.51)$ \\
\hline 5. Milk + concentrate + hay & 1.56 & 0.016 & $4.79(2.18-10.52)$ \\
\hline \multicolumn{4}{|l|}{ Time with the its mother } \\
\hline 1. $<1$ hour & - & - & - \\
\hline 2. $1-5$ hours & 1.84 & 0.006 & $0.15(0.12-0.20)$ \\
\hline 3. $>5$ hours & 1.20 & 0.01 & $0.30(0.13-0.66)$ \\
\hline \multicolumn{4}{|l|}{ Contact with dogs } \\
\hline No & - & - & - \\
\hline Yes & 1.27 & 0.001 & $3.57(2.80-4.56)$ \\
\hline \multicolumn{4}{|l|}{ Giardia } \\
\hline \multicolumn{4}{|l|}{ Milk Supply } \\
\hline 1. Bottle & - & - & - \\
\hline 2. Bucket & -4.74 & 1 & $2.47(1.93-3.15)$ \\
\hline 3. Bottle + bucket & 1.68 & 0.003 & $5.40(1.18-6.58)$ \\
\hline 4. Without milk supply & -1.87 & 0.87 & $3.87(2.00-28.30)$ \\
\hline \multicolumn{4}{|l|}{ Eimeria } \\
\hline \multicolumn{4}{|l|}{ Floor } \\
\hline 1. Concrete & - & - & - \\
\hline 2. Slatted & -1.36 & 0.06 & $0.25(0.20-0.32)$ \\
\hline 3. Ground & -0.04 & 0.95 & $0.95(0.43-2.10)$ \\
\hline 4. Concrete + slatted & -3.48 & 0.01 & $0.03(0.02-0.03)$ \\
\hline \multicolumn{4}{|l|}{ Age } \\
\hline 1. 1 -15 days & - & - & - \\
\hline 2. $16-30$ days & 2.05 & 0.007 & $7.81(3.56-17.14)$ \\
\hline 3. $31-45$ days & 2.64 & $<0.001$ & $14.02(10.95-17.89)$ \\
\hline 4. $\geq 46$ days & 2.62 & 0.001 & $13.76(6.27-30.20)$ \\
\hline
\end{tabular}

Brazil, observed lower prevalence (26.75\%). According to the literature, Giardia spp. cysts were observed in $9 \%$ of 120 fecal samples from calves aged 1 to 90 days (11). Additionally, in another study with 560 calves showed $17 \%$ (95) positivity for Giardia spp. (13). The index of positive animals in this study was similar to the global average rate $(25.56 \%)$ of calves shedding Giardia duodenale (14). According to the multivariate analysis, bovine milk supplied by bottle and bucket increased the chances of infection by Giardia spp. Furthermore, the calves age may influence this high percentage of positive samples for Giardia spp, since, in its majority, the prevalence was observed in animals up to four weeks of age (13). Corroborating to our findings, age was also found to be a highly significant risk factor for Giardia infection when Geurden et al (15) showed that calves had higher risk of being infected before reaching 8 weeks. This result is a significant finding, since it represents a risk to animal health, considering that Giardia spp is a worldwide important zoonotic agent (16). spp. Además, la edad de los terneros puede influir en el alto porcentaje de muestras positivas para Giardia spp, ya que la prevalencia fue mayormente observada en animales de hasta cuatro semanas de edad (13). Para corroborar nuestros hallazgos, también se encontró que la edad fue un factor de riesgo altamente significativo para la infección por Giardia según Geurden et al (15) quienes indicaron que los terneros presentan un mayor riesgo de ser infectados antes de alcanzar las 8 semanas. Este resultado corresponde a un hallazgo significativo, ya que representa un riesgo para la salud animal, si se considera que Giardia spp es un importante agente zoonótico a nivel mundial (16).

Nuestros resultados muestran que la prevalencia de infección protozoaria por Eimeria fue del $21.81 \%$, lo cual representa un índice reducido en comparación con los reportados por otros investigadores (17), mientras que el análisis de 720 muestras de heces indicó la presencia de oocistos de Eimeria spp. en el $43,60 \%$ de las muestras. La eimeriosis es una enfermedad que puede causar morbilidad severa, afectando el crecimiento y el rendimiento de los 
Our results show that the prevalence of protozoal infection caused by Eimeria was $21.81 \%$, a reduced index compared to those reported by researchers (17), while analyzing 720 samples of feces observed the presence of oocysts of Eimeria spp. in $43.60 \%$ of the samples. The eimeriosis is a disease that can cause severe morbidity, affecting animal growth and performance. Calves with positive diagnosis showed lower body weight gain than those Eimeria spp negative (18). Statistical analysis revealed that infection by Eimeria is easier to happen in concrete floors, depending on animal age. According to the literature, individual housing may reduce the risk for coccidiosis, and on the contrary risk of infection increases with the size of the herd, in addition, the most affected calves were between 3 to 13 months old (19).

Cryptosporidium spp. was detected in $20.99 \%$ of the samples in current study, similarly to the result observed in calves aged between 7 to 21 days, since they showed $21.62 \%$ of positivity for oocysts (13). Similarly, another study conducted in Nellore calves, showed that $25.38 \%(n=130)$ of the animals shed oocysts of this parasite in their feces (4). There is a report on a cryptosporidiosis outbreak in 2012 in a herd of 400 calves, from which 35 (8.75\%) got sick and 16 (4\%) died. This farm had high mortality (about 70 calves) in 2011 due to cryptosporidiosis, but the attempts to diagnosis the disease by parasitological tests and fecal cultures failed (20). In a study conducted in Argentina, a prevalence of $19.35 \%$ for Cryptosporidium spp. was found, similarly to the results observed in our study (21). In a work developed by Carvalho et al (22), infection by Cryptosporidium spp. was observed in all evaluated moments. In the current study, the multivariate analysis showed several ways on how calves could become infected by Cryptosporidium spp. The main reasons for infection may have been the food, especially by concentrate, followed by the length of time with cow postpartum, and contact dogs. These last two are risk factors easily understood, since adult animals usually are carriers of cryptosporidiosis, eliminating the agent in the feces, contaminating the environment. By analyzing infection by Cryptosporidium parvum, researchers have identified different risk factors, such as the use of buckets to feed the calves and supplementation with fermented milk (23).

The occurrence of diarrhea recorded in our study $(25.51 \%)$ confirms the relevance of this clinical sign for calves, and it revealed that animales. Los terneros con diagnóstico positivo mostraron una menor ganancia de peso corporal que los Eimeria spp negativos (18). El análisis estadístico reveló que la infección por Eimeria ocurre con mayor facilidad en pisos de concreto, según la edad del animal. Según la literatura, la vivienda individual puede reducir el riesgo de coccidiosis, y por el contrario el riesgo de infección aumenta con el tamaño del rebaño, además, los terneros que se vieron más afectados tenían entre 3 y 13 meses de edad (19).

En el presente estudio encontró Cryptosporidium spp. en el $20,99 \%$ de las muestras, resultado similar a aquel observado en terneros de edades comprendidas entre 7 y 21 días, los cuales mostraron un $21.62 \%$ de positividad para ooquistes (13). Del mismo modo, otro estudio realizado en terneros Nelore mostró que el $25.38 \%(n=130)$ de los animales depositaron oocistos de este parásito en sus heces (4). Existe un informe acerca de un brote de criptosporidiosis que se presentó en un rebaño de 400 terneros en 2012, de los cuales 35 $(8.75 \%)$ cayeron enfermos y $16(4 \%)$ fallecieron. Esta granja presentaba una elevada mortalidad (alrededor de 70 terneros) en 2011 causada por criptosporidiosis, pero fracasaron los intentos de diagnosticar la enfermedad por medio de pruebas parasitológicas y cultivos fecales (20). En un estudio realizado en Argentina, se encontró una prevalencia de $19,35 \%$ para Cryptosporidium spp., resultado similar a lo observado en nuestro estudio (21). En un trabajo desarrollado por Carvalho et al (22), la infección por Cryptosporidium spp. se observó en todos los momentos de evaluación. El análisis multivariado realizado en este estudio mostró varias maneras en las que los terneros podían ser infectados con Cryptosporidium spp. Los principales motivos de infección pueden haber sido los alimentos, especialmente en forma de concentrado, seguido por el tiempo junto a la vaca en el postparto y el contacto con perros. Estos dos últimos son factores de riesgo fácilmente comprensibles, ya que los animales adultos suelen ser portadores de criptosporidiosis, eliminando el agente en las heces y contaminando el medio ambiente. Al analizar la infección por Cryptosporidium parvum, los investigadores han identificado distintos factores de riesgo, como lo son el uso de baldes para alimentar a los terneros y la suplementación con leche fermentada (23).

La incidencia de diarrea registrada en nuestro estudio (25.51\%) confirma la relevancia de este signo clínico en terneros, y reveló que aproximadamente el $50 \%$ de los terneros con diarrea eran positivos para la presencia de al menos un protozoario. En otro estudio en donde se evaluaron 1.974 terneros, los investigadores encontraron que el $19.75 \%$ de ellos presentaba 
approximately $50 \%$ of calves with diarrhea were positives for at least one protozoan. In another study evaluating 1,974 calves, researchers found that $19.75 \%$ showed feces soft to liquid in consistency, a diarrhearic characteristic (3). Souza et al. (24) reported that diarrhea is a relatively common problem in calves (28.04\%) and mainly caused by viral and/or bacterial (54.93\%) agents. Although this work did not investigate viruses and bacteria, the percentage of infected samples points to protozoa. However, diarrhea can be triggered by the interaction of several factors such as bacteria, viruses, protozoa, immune deficiencies and environmental characteristics. Carvalho et al (22) reinforce this possibility because in their study they showed that the association between pathogens occurs from the first day of the diarrhea onset. It is important to emphasize that in this study the percentage of calves with normal feces represented $74.49 \%$; however, more than $50 \%$ were positives for at least one of the protozoa investigated. Some infected calves had normal fecal consistency, probably linked them to mild degree of infection. Again, this can be a complicating factor because, according to this study, asymptomatic animals are potential carriers of cysts/oocysts and considered important sources of transmission to healthy calves, acting as environmental contaminants (25).

Helminth's eggs of the Trichostrongylidae family were found in a very low number of samples, probably because a small portion of the animals had more than 30 days of life and limited contact with pastures. The provision of the roughage to the calves usually occurs after 30 days of age, and this factor favors the gastrointestinal helminth infection, since the animal is likely to ingest the larvae present in pastures $(2,7)$.

Based on these results, we concluded that infection by Giardia spp, Cryptosporidium spp, and Eimeria spp is substantially higher in calves, and might be interfering with animal growth leading to poor performance as a result of the intestinal damage cause by them. There was no a relation between the occurrence of diarrhea and parasitism in the statistical analysis of cause-effect. This study identified risk factors for infection such as food, time spent with the cow during postpartum and contact with dogs. These are risk factors for Cryptosporidium spp, while the milk supply was a risk factor for Giardia spp, and the floor type and age were risk factors for Eimeria spp. infection. heces con una consistencia de blanda a líquida, lo cual es una característica diarreica (3). Souza et al (24) reportaron que la diarrea es un problema relativamente común en terneros (28.04\%), cuya causa principal son principalmente los agentes virales y/o bacterianos (54.93\%). Aunque el presente estudio no investigó virus y bacterias, el porcentaje de muestras infectadas indica que se trata de protozoos. Sin embargo, la diarrea puede ser desencadenada por la interacción entre varios factores como bacterias, virus, protozoos, deficiencias inmunológicas y características ambientales. Un estudio de Carvalho et al (22) refuerza esta posibilidad, ya que demostró que la asociación entre patógenos ocurre desde el primer día de inicio de la diarrea. Es importante destacar que en este estudio el porcentaje de terneros con heces normales representó el 74.49\%; Sin embargo, más del $50 \%$ fueron positivos para al menos uno de los protozoarios bajo investigación. Algunos terneros infectados tenían una consistencia fecal normal, que probablemente estaba ligada a un grado de infección leve. Nuevamente, este puede ser un factor que causa complicaciones porque, según lo muestra este estudio, los animales asintomáticos son potenciales portadores de quistes/oocistos y son consideradas fuentes importantes en la transmisión a terneros sanos, funcionando como contaminantes ambientales (25).

Los huevos de helminitos la familia Trichostrongylidae se encontraron en una cantidad de muestras muy reducida, lo que probablemente se debe a que una pequeña parte de los animales tenía más de 30 días de vida y un contacto con pastos limitado. A los terneros se les suele alimentar con forraje después de los 30 días de edad, factor que favorece la infección gastrointestinal por helmintos, ya que es probable que el animal ingiera las larvas que se encuentran en los pastos $(2,7)$.

Con base en estos resultados, concluimos que la infección por Giardia spp, Cryptosporidium spp y Eimeria spp es sustancialmente más alta en terneros, en donde el daño intestinal que éstos ocasionan podría estar interfiriendo con el crecimiento de los animales y conduciendo a un bajo rendimiento. El análisis estadístico de causa-efecto no encontró relación alguna entre la aparición de diarrea y el parasitismo. Este estudio identificó factores de riesgo de infección tales como alimentos, tiempo junto a la vaca durante el postparto y contacto con perros. Estos son factores de riesgo de infección por Cryptosporidium spp, mientras que el suministro de leche fue un factor de riesgo para Giardia spp, y el tipo de suelo y la edad fueron factores de riesgo para Eimeria spp. 
Ethics Committee. The experiment was approved by the Ethics Committee in Research with Animals of the Universidade do Estado de Santa Catarina (UDESC), under protocol number 1.26 .15
Comité de Ética. El presente experimento tuvo la aprobación del Comité de Ética en Investigación con Animales de la Universidad del Estado de Santa Catarina (UDESC) bajo el número de protocolo 26/01/15.

\section{REFERENCES}

1. FAO - Food and Agriculture Organization of the United Nations. Roma: FAO Statistical Yearbook, 2013.

2. Maia GBS, Pinto AR, Marques CYT, Roitman FB, Lyra DD. Produção Leiteira no Brasil. BNDES Setorial 2013; 37(1):371-398.

3. Botteon RCCM, Botteon PTL, Júnior Santos JCB, Pinna MH, Lóss ZG. Frequência de diarreia em bezerros mestiços sob diferentes condições de manejo na região da média Paraíba - Rio de Janeiro e Minas Gerais. Braz J Vet Res Anim Sci 2008; 45(2):153-160.

4. Oliveira Filho JP, Silva DPG, Pacheco MD, Mascarini LM, Ribeiro MG, Alfieri AA, Alfieri AF, Stipp DT, Barros BJP, Borges AS. Diarreia em bezerros da raça Nelore criados extensivamente: estudo clínico e etiológico. Pesq Vet Bras 2007; 27:419-424.

5. Wattiaux MA. Essenciais em Gado de LeiteCriação de Novilhas. The Babcock Institute: University of Wisconsin-Madison; 2012.

6. Sharma S, Vijayachari P, Sugunan AP. Histopathological studies of Eimeria bovis infection in Calves. J Veterinar Sci Technol 2015; 6(1):235.

7. Bastiani FT, Da Silva AS, Dück MRK, Tonin AA, Monteiro SG. Outbreak of eimeriosis and giardiasis associated to mortality of lambs in southern Brazil. Comp Clin Pathol 2012; 21(3): 371-373.

8. Meireles GS, Silva NMP, Galvão GS, Almeida CRR, Flausino W, Lopes CWG. Surto de coccidiose em bezerros búfalos (Bubalus bubalis) por Eimeria bareillyi GIL et al., 1963 (Apicomplexa: Eimeriidae) - Relato de casos. Rev Bras Med Vet 2012; 34(2):116-120.

9. Couto MCM, Bomfim TCB. Espécies de Cryptosporidium que infectam bovinos: características etiológicas e epidemiológicas. Vet Not 2012; 18(2):94-109.
10. Martins-Vieira MBC, Brito LAL, Heller L. Oocistos de Cryptosporidium parvumem fezes de bezerros infectados experimentalmente. Arq Bras Med Vet Zootec 2009; 61(6):14541458.

11. Guimarães AM, Guedes E, Carvalho RA. Ocorrência de Giardia spp. em bezerros leiteiros no Brasil. Arq Bras Med Vet Zootec 2011; 53(6):652-653.

12. Gressler LT, Silva AS, Silva MK, Tonin AA, Monteiro SG. Gastrointestinal parasites of cavy (Cavia aperea aperea) in southern Brazil. Res Vet Sci 2010; 89(2):206-208.

13. Gow S, Waldner C. An examination of the prevalence of and risk factors for shedding of Cryptosporidium spp. and Giardia spp. in cows and calves from western Canadian cow-calf herds. Vet Parasitol 2006;137(1-2): 50-61.

14. Silva Júnior FA, Carvalho AHO, Rocha CMBM, Guimarães AM. Fatores de risco associados à infecção por Cryptosporidium spp. e Giardia duodenalis em bovinos leiteiros na fase de cria e recria na mesorregião do Campo das Vertentes de Minas Gerais. Pesq Vet Bras 2011; 31(8):690-696.

15. eurden $T$, Vanderstichel $R$, Pohlec $H$, Ehsan $A$, von Samson-Himmelstjerna G, Morgan ER, et al. A multicenter prevalence study in Europe on Giardia duodenalis in calves, with molecular identification and rick factor analysis. Vet Parasitol 2012; 190: 383-390.

16. Hunter PR, Thompson ARC. The zoonotic transmission of Giardia and Cryptosporidium. Int J Parasitol 2005; 35(12):1181-1190.

17. Rebouças MM, Grasso LMPS, Filha Spósito E, Amaral V, Santos SM, Silva DM. Prevalência e distribuição de protozoários do gênero Eimeria (Aplicomplexa: Eimeriidae) em bovinos nos municípios de Altinópolis, Taquaritinga, São Carlos e Guaíra - Estado de São Paulo, Brasil. Rev Bras Parasitol Vet 1994; 3(2): 125-130. 
18. Bangoura B, Daugschies A. Parasitological and clinical parameters of experimental Eimeria zuernii infection in calves and influence on weight gain and haemogram. Parasitol Res 2007; 100(6):1331-1340.

19. Tomczuk K, Grzybek M, Szczepaniak K, Studzinska M, Demkowska-Kutrzepa M, Roczen-Karczmarz M, Klockiewicz M. Analysis of intrinsic and extrinsic factors influencing the dynamics of bovine Eimeira spp. From centrl-eastern Poland. Vet Parasitol 2015; 214(1):22-28.

20. Vargas Jr SF, Marcolongo-Pereira C, Adrien ML, Fiss L, Molarinho KR, Soares MP, Schild $A L$, Sallis ESV. Surto de criptosporidiose em bezerros no Sul do Rio Grande do Sul. Pesq Vet Bras 2014; 34(8):749-752.

21. Tiranti K, Larriestra A, Vissio C, Picco N, Alustiza F, Degioanni A, Vivas A. Prevalence of Cryptosporidium spp. and Giardia spp., spatial clustering and patterns of shedding in dairy calves from Córdoba, Argentina. Rev Bras Parasitol Vet 2011; 20(2):140-147.
22. Carvalho JG, Carvalho AU, Heinemann MB, Coelho SG, Paes PRO, Moreira GHFA, Vespasiano LC, Filho Facury EJ. Estudo longitudinal da infecção por enteropatógenos em bezerros neonatos, com diarreia, sob diferentes estratégias de aleitamento. Pesq Vet Bras 2014; 34(6):529-536.

23. Delafosse A, Chartier C, Dupuy MC, Dumoulin M, Pors I, Paraud C. Cryptosporidium parvum infection and associated risk factors in dairy calves in western France. Prev Vet Med 2015; 118:406-412.

24. Sousa MV, Gonçalves RC, Lisbôa JAN, Almeida CT, Chiacchio SB. Aspectos clínicos e epidemiológicos da diarréia dos bezerros em Botucatu, SP. Rev Bras Ciênc Vet 2010; 79(2): 74-77.

25. Feitosa FLF, Shimamura GM, Roberto T, Mendes LCN, Peiró JR, Féres FC, Bovino F, Perri SHV, Meireles MV. Importância de Cryptosporidium spp. como causa de diarreia em bezerros. Pesq Vet Bras 2008; 28(10):452-456. 